\title{
Sprawozdanie z konferencji "English Law and Colonial Connections: Histories, Parallels, and Jnfluences". On-line Conference
}

\begin{abstract}
Report of the "English Law and Colonial Connections: Histories, Parallels, and Influences". On-line Conference

The: "English Law and Colonial Connections: Histories, Parallels, and Influences conference" was held over the course of two afternoons, on January 26-27, 2020. It was organized by the Faculty of Law and Administration of the University of Łódź and Northumbria University in Newcastle. The symposium's goal was to bring together researchers with interests in the history of English law and its influences on other parts of the world, particularly within an imperial context. An additional topic of the conference was the meaning of legacies and continuing influences of the empire and colonial influences of the law back to the Metropole. Nine lectures were delivered over the course of four sessions.
\end{abstract}

Keywords: conference, legal history, English law, colonies, empire

Słowa kluczowe: konferencja, historia prawa, historia prawa angielskiego, prawo angielskie, kolonie, imperium

W dniach 26-27 stycznia 2021 r., na platformie komunikacyjnej Zoom, odbyła się międzynarodowa konferencja naukowa „English Law and Colonial Connections: Histories, Parallels, and Influences", organizowana przez Wydział Prawa i Administracji Uniwersytetu Łódzkiego oraz Northumbria University (Newcastle).

Spotkanie otworzył dr hab. Tomasz Bekrycht, prof. UŁ, prodziekan ds. nauki WPiA UŁ. Witając wszystkich prelegentów i słuchaczy, odniósł się do znaczenia badań nad prawem angielskim i jego oddziaływaniach na terytorium Imperium.

Konferencja składała się z czterech paneli, podczas których wygłoszono dziewięć wystąpień. Prelegentami byli naukowcy z ośrodków naukowych w Niemczech, Polsce, Stanach Zjednoczonych oraz Wielkiej Brytanii. Pierwszego dnia zaplanowano dwie se- 
sje, które poprowadziła dr Cerian Griffiths (Northumbria University). Jako pierwszy, swój referat nt. It seems history is to blame: Imagination and the Colonial Challenge to English Legal History zaprezentował Richard Ireland (Aberystwyth University). Następnie dr Matilde Cazzola (Max Planck Institute for European Legal History) wygłosiła prelekcję nt. To Remake Britain in the Image of the Raj: James Fitzjames Stephen and India as a Legal Model. Po przerwie dr Sally Hadden (Western Michigan University) zaprezentowała wystąpienie dotyczące London's Middle Temple and Law Students from the New World. Ostatnim prelegentem tego dnia był dr hab. Łukasz J. Korporowicz, prof. UŁ (Uniwersytet Łódzki) przedstawiający referat pod tytułem Sir James Mackintosh - Barrister, Judge, Law Professor.

Drugiego dnia sesje prowadził dr hab. Łukasz J. Korporowicz, prof. UŁ. Jako pierwsza wystąpiła dr Cerian Griffiths (Northumbria University) z prelekcją na temat Fraud and the City of London: Global Opportunities in the Eighteenth-Century. Następnie prof. Michael Lobban (London School of Economics and Political Science) wygłosił referat nt. Authority and Subjecthood at the Margins of Empire: the Case of Sekgoma Letsholathibe. Sesję zakończyła prelekcja prof. Julii E. Rudolph (North Carolina State University) nt. The Last Will and Testament of John Gardner Kemeys: Jamaican Mortgages and English Inheritance Disputes. Po krótkiej dyskusji wystąpił prof. Stefan Vogenauer (Max Planck Institute for European Legal History) z referatem dotyczącym Influences of English Law on Asian Contract Laws: Contractual Interpretation. Na zakończenie wyniki swoich badań przedstawił dr Jan Halberda (Uniwersytet Jagielloński), wygłaszając referat na temat The Principle of Good Faith and Fair Dealing in AngloAmerican Contract Law. Intensywne debaty po każdym z paneli dotyczyły nie tylko znakomitych referatów, ale również odniesień do zagadnień badawczych, nad którymi, zdaniem uczestników spotkania, należałoby się pochylić. Ożywiona dyskusja inspirowała zwłaszcza do podjęcia badań nad XIX w., którego spuścizna wciąż czeka na dogłębne opracowanie.

Organizatorzy, zapraszając prelegentów do udziału, nie wskazali ram czasowych ani ograniczeń jurysdykcyjnych zagadnień badawczych. Dzięki temu udało się zorganizować konferencję, która szeroko omawiała zarówno wpływ prawa angielskiego na tworzenie i stosowanie prawa $w$ innych częściach świata, oddziaływania kolonii na metropolię, jak i spuściznę prawniczą Imperium. W dygresjach uczestników spotkania pojawiały się uwagi, że pandemiczna rzeczywistość wymusiła sporo zmian w ich sposobie pracy. Zamknięto archiwa i biblioteki, odwołano lub przełożono kongresy i konferencje, które na stałe wpisane były w życie uniwersyteckie. Jednocześnie podkreślano, jak konieczność prowadzenia dyskusji akademickich on-line sprawiła, że zorganizowanie interesującej konferencji międzynarodowej stało się o wiele prostsze. A to spotkanie należy do takich sukcesów zaliczyć. Pozostaje mieć nadzieję, że konferencja „English Law and Colonial Connections" stanie się wydarzeniem cyklicznym, pozwalającym na wymianę myśli i poglądów wśród specjalistów z całego świata. 